\title{
Paralytic toxin profiles of xanthid crab Atergatis floridus collected on reefs of Ishigaki Island, Okinawa Prefecture, Japan and Camotes Island, Cebu Province, Philippines
}

\author{
Manabu Asakawa ${ }^{1,}$,, Shintaro Tsuruda ${ }^{1}$, Yasuyuki Ishimoto ${ }^{1}$, Michitaka Shimomura ${ }^{2}$, \\ Kazuo Kishimoto $^{3}$, Yasuo Shida ${ }^{4}$, Mercy Barte-Quilantang ${ }^{5}$, Gloria Gomez-Delan ${ }^{6}$ \\ ${ }^{1}$ Department of Biofunctional Science and Technology, Food Science and Biofunctions Division, Graduate School of Biosphere Science, \\ Hiroshima University, 1-4-4 Kagamiyama, Higashi-Hiroshima, Hiroshima 739-8528, Japan \\ ${ }^{2}$ Kitakyushu Museum of Natural History \& Human History, Kitakyushu, Fukuoka 805-0071, Japan \\ ${ }^{3}$ Okinawa Prefectural Fisheries Research and Extention Center, Ishigaki Branch, Ishigaki, Okinawa 907-0453, Japan \\ ${ }^{4}$ Tokyo University of Pharmacy and Life Science, Hachioji, Tokyo 192-0392, Japan \\ ${ }^{5}$ Institute of Fish Processing Technology, College of Fisheries and Ocean Sciences, University of the Philippines Visayas, Miagao, 5023 \\ Iloilo, Philippines \\ ${ }^{6}$ College of Fisheries Technology, Cebu Technological University - Carmen, Cebu Campus, 6005, Cebu, Philippines
}

\section{Email address:}

asakawa@hiroshima-u.ac.jp (M. Asakawa)

\section{To cite this article:}

Manabu Asakawa, Shintaro Tsuruda, Yasuyuki Ishimoto, Michitaka Shimomura, Kazuo Kishimoto, Yasuo Shida, Mercy Barte-Quilantang, Gloria Gomez-Delan. Paralytic Toxin Profiles of Xanthid Crab Atergatis Floridus Collected on Reefs of Ishigaki Island, Okinawa Prefecture, Japan and Camotes Island, Cebu Province, Philippines. Science Journal of Clinical Medicine.

Vol. 3, No. 5, 2014, pp. 75-81. doi: 10.11648/j.sjcm.20140305.11

\begin{abstract}
Attempts were made to assess the toxicity and to analyze paralytic toxin profiles of xanthid crab Atergatis floridus collected on two reefs on the left- and the right-side, tentatively designated as site A and B, separated by the passage at the outside of Kabira Bay in Ishigaki Island, Okinawa Prefecture, Japan in comparison with those of the same crabs from Camotes Island off the eastern coast of Cebu Island, Cebu Province, Philippines. They were dissected into 4 parts; carapace, viscera, appendage and muscle of appendage. Muscle of appendage was highly toxic, and the maximum toxicity of 4,641 $\pm 972 \mathrm{MU} / \mathrm{g}$ as paralytic shellfish poison (PSP) was recorded in the specimens from the right-side reef (site B). Toxicity assays showed that all of them were toxic irrespective of the crab-collecting years, locations, and tissues, and in addition to these, there seemed to be marked narrow regionality and individual variation of toxicity and toxin profiles. Toxicity of Ishigaki specimens was seemed to be higher than that of Camotes specimens. Toxin profiles of the viscera of A.floridus were examined by high performance liquid chromatography-fluorescent detection (HPLC-FLD) analysis. In the viscera of A.floridus from site A in June, 2007, relative abundances (mole \%) of carbamoyl- $N$-hydroxyneosaxitoxin (hyneoSTX), neosaxitoxin (neoSTX), and saxitoxin (STX) were high (98\%), and only $2 \%$ of gonyautoxin 2(GTX2) were contained in addition to similar amounts (3\%) of decarbamoylsaxitoxin (dcSTX). Its viscera from site B in the same month possessed GTX2 (36\%) and STX group (63\%) predominantly, and only 1\% of GTX1 was contained in addition to similar amount (2\%) of STX. Their viscera possessed STX group as the major components (89\%) along with the GTX4 (11\%) as the minor. On the other hand, PSP compositions of the viscera of Camotes specimen resembled to that of the viscera from the specimens on site A in Kabira Bay with higher GTX4 but lower hyneoSTX. A solitary outstanding difference of toxin profiles in both crabs was the occurrence of tetrodotoxin (TTX) in the Camotes specimen due to the results of HPLC-FLD and gas chromatography-mass spectrometry (GC-MS) analysis.
\end{abstract}

Keywords: Xanthid Crab, Atergatis floridus, Paralytic Shellfish Poison, Tetrodotoxin, Ishigaki Island, Camotes Island, Philippines, HPLC-FID, GC-MS, Gonyautoxin, Saxitoxin 


\section{Introduction}

Paralytic shellfish poison (PSP), a most hazardous marine toxin, mainly originates in toxic marine dinoflagellates species of the genera Alexandrium, Gymnodinium and Pyrodinium, are accumulated in many species of marine organisms such as crabs and filter-feeding organisms such as bivalve mollusks $[1,2,3]$. These organisms can act as potential toxin vectors and pose a threat to human health. Within these PSP containing organisms, it has so far been reported that three species of xanthid crabs, "subesube-manjyugani" Atergatis floridus, "umore-ougigani" Zosimus aeneus, and "tsubuhiraashi-ougigani" Platypodia granulosa, in the family Xanthidae inhabiting tropical and subtropical areas, contain PSP such as saxitoxin (STX) and neosaxitoxin (neoSTX) $[4,5,6]$. One of these toxic crabs, A. floridus (Floral egg crab) widely inhabits even in temperate area as well as in tropical and subtropical areas while the other two species not in temperate area. In Japan, it inhabits also the Japan Proper and adjacent islands of the Amami and the Ryukyu but its toxicity and toxin profile varied [7, 8, 9]. There are a number of unclarified points regarding toxification mechanisms of these crabs until now.

The present report therefore aims at presenting basic data on it. Then, at first, we tried to collect A.floridus specimens in Ishigaki Is., Okinawa Prefecture, the southern-east area in Japan, and the Camotes Is. in the Camotes Sea off the eastern coast of Cebu Island, Cebu Province, Visayas region of the Philippines. By using these samples, attempts were made to examine two points as follows. The first is to examine details of toxicity and the toxin profiles of A.floridus between the two reefs, which are separated by a passage, within very close distance as a part of the study on toxification mechanism of toxic xanthid crabs. In this connection, the second is to examine details of toxicity and the toxin profiles of A.floridus from two subtropical areas, Ishigaki Is. and Camotes Is. This paper deals these results obtained.

\section{Materials and Methods}

\subsection{Materials}

Figure 1 shows two sampling locations of reefs in Kabira Bay, Ishigaki Island, Okinawa Prefecture, Japan. There are the two reefs, on the left- and the right-side at the outside of the Bay, which are separated by the passage. Here, they are tentatively designated as site A (N24.46934, E124.14392) and B (N24.46630, E124.14685), respectively.

Total fifteen crab specimens were collected on reefs in every June, 2007, 2009 and 2010. At an ebb-tide, these reefs appear and specimens of xanthid crab were collected easily by hand. On the other hand, on reefs along San Francisco (N10.64762, E124.38206) in Camotes Is., Cebu Province, Visayas region of Philippines (Figure.2), five specimens were collected by fishermen using crab cages in August 2009. All the specimens mentioned above were immediately frozen after capture, transported by air to our laboratory, and kept frozen at $-20^{\circ} \mathrm{C}$ prior to identification and toxin profiles analysis. All of them were identified as the xanthid crab Atergatis floridus (Linnaeus, 1767) by Dr. M.Shimomura, one of our authors, from the Kitakyushu Museum of Natural History \& Human History (Figure.3, [10]).
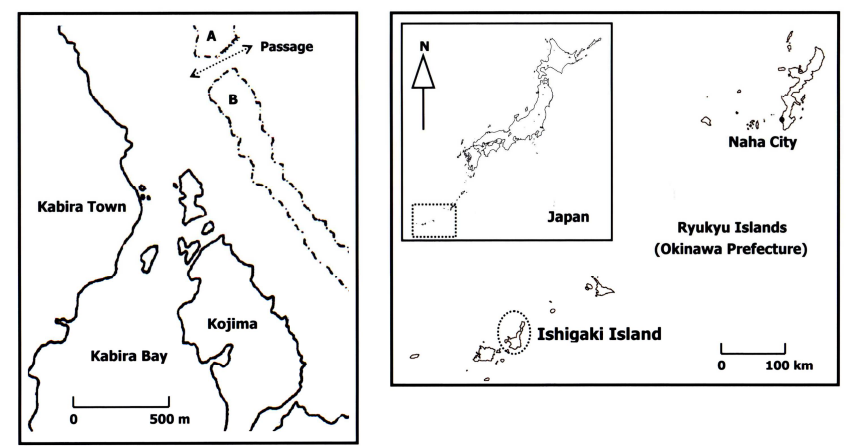

Figure 1. Map showing crab-collecting locations in Ishigaki Island. The location of Ishigaki Island in Japan is shown in the map to the right. The map on the left shows an enlarged image of Ishigaki Island to pinpoint the sampling location.

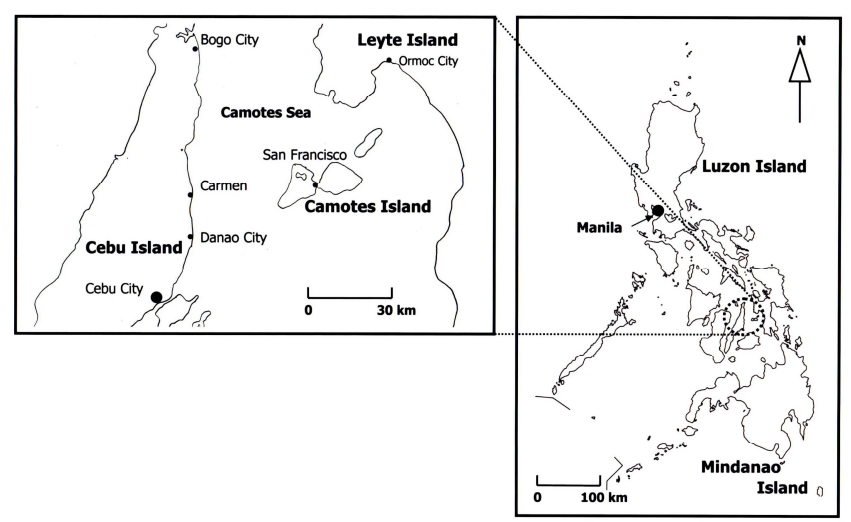

Figure 2. Map showing crab-collecting locations in Camotes Island. The location of Camotes Island in the Philippines is shown in the map to the right. The map on left shows an enlarged image of Camotes Island to pinpoint the sampling location.
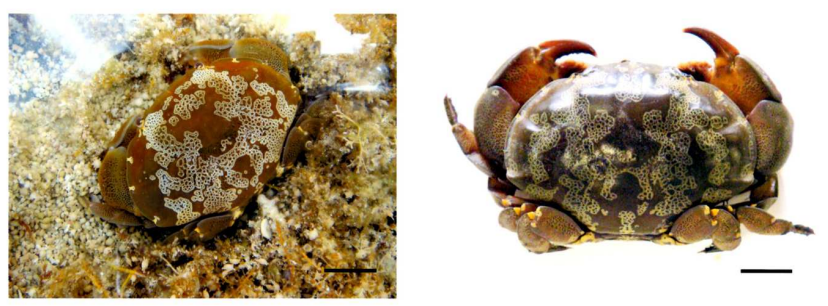

Figure 3. Toxic xanthid crab Atergatis floridus; (I) A live specimen on reefs outside of Kabira Bay, Ishigaki Island, Okinawa Prefecture, Japan is shown to the left. (II); A specimen on reefs along the town of San Francisco in Camotes Is., Philippines is shown to the right. $\quad($ Scale bar $=1.0 \mathrm{~cm})$

\subsection{Assay for Lethal Potency}

Each crab was partially thawed and dissected into four anatomically different parts: carapace, viscera including hepatopancreas, reproductive organs, and intestines, appendages torn off from each crab specimen and muscles 
in the appendages, which called muscles below. We examined toxicity for each tissue by the standard bioassay for PSP [11]. Lethality was expressed in mouse units per gram of crab specimen tissue $(\mathrm{MU} / \mathrm{g})$, where one $\mathrm{MU}$ is the amount of intraperitonially (i.p.) administered toxic material required to kill a $18-20 \mathrm{~g}$ male mouse of the $\mathrm{ddY}$ strain in $15 \mathrm{~min}$.

\subsection{Purification of Toxins}

Each viscera from crab specimens collected on reefs (site A and B) in Ishigaki Is., June, 2009 were used as material, and then 3 volumes of $1 \%$ acetic acid in $80 \%$ methanol was added. The mixture was homogenized for $3 \mathrm{~min}$ and extracted under reflux. This operation was repeated on the residue twice after filtration. The filtrate was combined and, concentrated under reduced pressure. Extracts (total toxicity: 1,172MU and 249MU as PSP for the left- and the right-side reef crab specimen, respectively) were defatted with dichloromethane, and the aqueous layer was partially purified by successive treatment on activated charcoal (Wako) and Bio-Gel P-2 (Bio-Rad. Lab.) column chromatography. Conditions for each procedure were similar to those in the previous studies [12]. Toxicity was detected exclusively in the $0.03 \mathrm{M} \mathrm{AcOH}$ fraction obtained from Bio-Gel P-2 column chromatography. This toxic fraction was concentrated to dryness under reduced pressure, and the partially purified toxin obtained was dissolved in a small amount of water, and analyzed for PSP and tetrodotoxin (TTX) by HPLC-FLD as previously described $[1,12,13,14]$. A LiChroCART RP-18(e) column ( $\varphi 4.0 \mathrm{x}$ $250 \mathrm{~mm}$, Merck) was used in combination with the two mobile phases. In addition, an alkali-hydrolysate of this toxin was trimethylsilylated and analyzed by gas chromatography-mass spectrometry (GC-MS), as described below.

Standards of PSP and TTX were used in the previous report $[14,15,16]$. The acidified $\mathrm{MeOH}$ extract (7,443 MU as PSP) from the viscera of Camotes specimen was prepared by the same methods was subjected the almost the same methods mentioned above.

\subsection{Gas Chromatography-Mass Spectrometry}

The trimethylsilyl (TMS) derivative of 2 - amino - 6 hydroxymethyl - 8 - hydroxyquinazoline (C9 base), was derived from purified toxins and authentic TTX by a previously described procedure [17]. Both TMS derivatives were injected to a Varian gas chromatograph (1200 MS/MS) equipped with a mass spectrometer (Varian CP-3800) according to previously described methods $[12,13]$.

\section{Results and Discussions}

As shown in Table, all of the crab specimens used in this study were found to be toxic as expected. The frequency of toxic samples was $100 \%$ in Ishigaki specimens and their toxicities were widely distributed in various tissues. Though toxicity assays showed that all of them were toxic and induced paralytic symptoms typical of PSP irrespective of crab-collecting locations (site A and B), there are remarkable individual variations in anatomical distribution of toxicity. Distributions of PSP toxicity scores in each tissue in Ishigaki specimens were as follows; carapace from $183 \pm 47$ to $807 \pm 693 \mathrm{MU} / \mathrm{g}$, viscera from $64 \pm 41$ to $654 \pm 137 \mathrm{MU} / \mathrm{g}$, appendages from $88 \pm 40$ to $1,257 \pm 607 \mathrm{MU} / \mathrm{g}$ and their muscle from 1,408 \pm 404 to $4,641 \pm 972 \mathrm{MU} / \mathrm{g}$ (Av. \pm S.D.), respectively. On the other hand, all of the Camotes Is. specimens also showed high toxicities in each tissue as follows; viscera (105 \pm 56 $\mathrm{MU} / \mathrm{g})$, appendages $(221 \pm 189 \mathrm{MU} / \mathrm{g})$ and their muscle $(719 \pm 349 \mathrm{MU} / \mathrm{g})$ (Av. \pm S.D.), respectively. It is also reported that muscle of appendages showed highest toxicity $(1,100-5,900 \mathrm{MU} / \mathrm{g})$ irrespective of the specimens of A.floridus and Z.aeneus from Ishigaki Island [18]. Toxicity of Camotes specimens was seemed to be lower in comparison with that of Ishigaki specimen with the highest score of 5,613 MU/g (Site B, June 200).

Table. Toxicity of xanthid crab Atergatis floridus collected on the reefs of Ishigaki Island, Okinawa Prefecture, Japan and Camotes Island, Cebu Province, Philipines

\begin{tabular}{|c|c|c|c|c|c|c|c|c|}
\hline \multicolumn{9}{|c|}{ (A) Okinawa Prefecture, Japan } \\
\hline \multirow{2}{*}{$\begin{array}{l}\text { Month, Year of } \\
\text { Collection }\end{array}$} & \multirow{2}{*}{\multicolumn{2}{|c|}{ Place of Collection }} & Number of & Body Weight (g) & Toxicity (I & \pm S.D. & & \\
\hline & & & Specimens & Av. $\pm \mathrm{SD}$ & Carapace & Viscera & Appendage & Muscle \\
\hline \multirow{2}{*}{ June, 2007} & \multirow{5}{*}{$\begin{array}{l}\text { Ishigaki } \\
\text { Island }\end{array}$} & Site A & 3 & $18 \pm 8$ & NT & $64 \pm 41$ & $88 \pm 40$ & NT \\
\hline & & Site B & 3 & $30 \pm 3$ & NT & $253 \pm 203$ & $113 \pm 115$ & NT \\
\hline \multirow{2}{*}{ June, 2009} & & Site A & 3 & $20 \pm 5$ & $183 \pm 47$ & $484 \pm 255$ & $503 \pm 179$ & $1,408 \pm 404$ \\
\hline & & Site B & 3 & $23 \pm 4$ & $807 \pm 693$ & $532 \pm 200$ & $856 \pm 700$ & $2,538 \pm 2,077$ \\
\hline June, 2010 & & Site B & 3 & $23 \pm 1$ & $332 \pm 49$ & $654 \pm 137$ & $1,257 \pm 607$ & $4,641 \pm 972$ \\
\hline \multicolumn{9}{|c|}{ (B) Cebu Province, the Philippines } \\
\hline \multirow{3}{*}{$\begin{array}{l}\text { Month and Year } \\
\text { of Collection } \\
\text { August, } 2009\end{array}$} & \multirow{2}{*}{\multicolumn{2}{|c|}{ Place of Collection }} & Number of & Body Weight (g) & \multicolumn{2}{|c|}{ Toxicity (MU/g) : Av. \pm S.D. } & & \\
\hline & & & Specimens & Av. $\pm \mathrm{SD}$ & Carapace & Viscera & Appendage & Muscle \\
\hline & Camotes & sland & 5 & $11 \pm 3$ & NT & $106 \pm 56$ & $221 \pm 189$ & $719 \pm 349$ \\
\hline
\end{tabular}

NT; not tested, Av; average, S.D.; standard deviation

As the food poisoning due to ingestion of toxic crabs sometimes occurs in the fisher folk of coastal areas in the Philippines, people should be warned of the potential hazard of this crab in order to prevent its intentional or accidental consumption due to by-catch. Though there is no habit to eat crabs from tropical or subtropical area in Japan, 
marine crabs form a part of the diet of many Filipinos. While most species are edible, some are unfortunately toxic to man and other mammals. Since the 1960s, at least seven cases of crab intoxication in Negros Oriental and the nearby Camotes Is., six of which were fatal, occurred [19]. Though the most common toxic species in this region is Demania cultripes, Lophozozymus pictor, Z. aeneus and so on[12, 20, 21, 22], A.floridus from Camotes Is. is highly toxic, too. So, it is important to supply food hygienic information on this toxic crab A.floridus for fishermen and inhabitants there. Since intake of toxin levels above 3,000 MU is assumed to be lethal to the adult human [23], consumption of some of the specimens of A.floridus could prove fatal. It is strongly advised that consumption of crabs living on reefs be avoided. In this connection, the results of lethality tests using whole bodies of all 35 A.floridus specimens from Fiji, Is. showed individual lethalities ranged widely from 3.4 to $717 \mathrm{MU} / \mathrm{g}$ [24].

The toxin partially purified from viscera of A.floridus collected on the reef (site B) in Ishigaki Is., June, 2007, showed a clear peak in HPLC-FLD chromatograms corresponding to the retention time of standards of PSP (Figure 4).
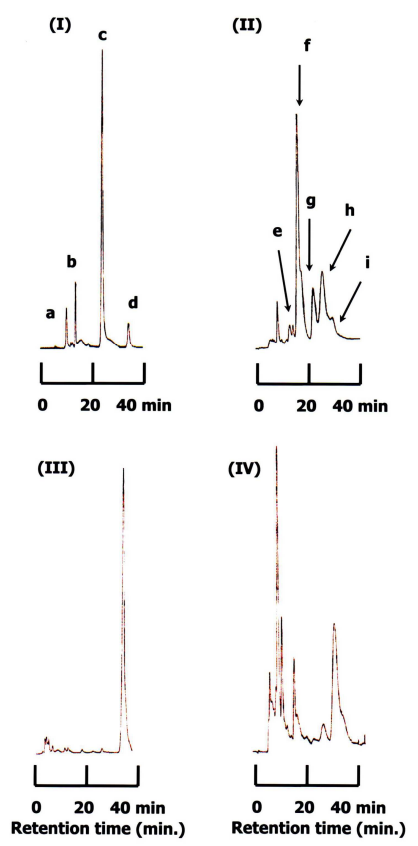

Figure 4. HPLC-FLD chromatograms of the purified toxins from the viscera in A.floridus collected on the reef (site B) of Ishigaki Island

(I): GTX stds. (a: GTX4, b:GTX1, c:GTX3, d:GTX2), (II) :STX stds. (e:hyneoSTX, f:neoSTX, g:hySTX, h:dcSTX, i:STX), (III) and (IV) : GTX and STX analysis of purified toxins from the viscera

For GTX analysis (Figure 4-I, III), the one main peak was identified as GTX2. In addition to this, GTX4, 1 and 3 were detected as trace components on the chromatogram. In STXs analysis (Figure 4-II, IV), the toxin revealed three peaks with the same retention times of hydroxyneosaxitoxin (hyneoSTX), neoSTX and STX, respectively. Toxin profiles of the viscera of A.floridus from site A and B in June, 2007 are illustrated in Fig.5.

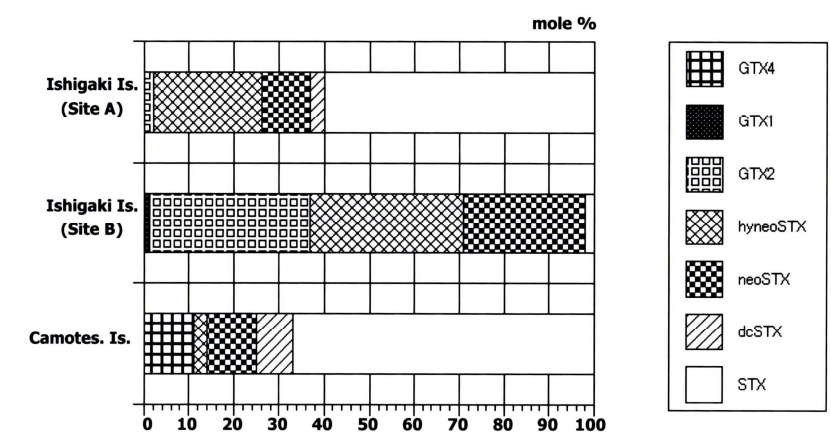

Figure 5. Comparison with the toxin profiles of A.floridus collected on reefs of Ishigaki Island and Camotes Island, Cebu Province, Philippines

In site A, relative abundances (mole \%) of carbamoyl- $N$-hydroxyneosaxitoxin (hyneoSTX), neosaxitoxin (neoSTX), and saxitoxin (STX) were high (98\%), and only $2 \%$ of gonyautoxin 2(GTX2) were contained in addition to similar amounts (3\%) of decarbamoylsaxitoxin (dcSTX). The viscera of A.floridus from site B in the same day possessed GTX2 (36\%) and STX group (63\%) predominantly, and only $1 \%$ of GTX1 was contained in addition to similar amount (2\%) of STX. Although the distance between site A and B were extremely near each other, there seemed to be marked narrow regionality of toxicity and toxin profiles. It was also reported that A.floridus on the reefs near Kabira Bay, Ishigaki Is. possessed STX predominantly over the other STX derivatives with no detectable amount of GTXs [18]. Such variation may be explainable, taking the spotty distribution of the causative agents into consideration. The reef on right-side is rocky, while the reef on left-side is bound in algae, especially, such as red algae and calcareous red alga. Kotaki et al., detected low levels of PSP in a calcareous alga Jania sp. and presumed its involvement in the intoxication of xanthid crabs the primary source of paralytic shellfish toxins in crabs and gastropods on the reef [25]. Later, TTX was also detected in this alga [26].

On the other hand, Saisho et al., reported the eating habits of the xanthid crabs, as examined from the composition of their stomach contents, irrespective of their PSP toxicity levels [27]. Judging from their results, the PSP containing highly toxic xanthid crabs such as Afloridus and Z.aeneus was postulated to be rather omnivorous (not planktonic) feeder than herbivorous. Actually, from stomach contents in A.floridus from Ishigaki Is. in June, 1979 Hypnea sp., sand, shell, animal tissues, poriferans and fish fragments with no parts of Jania sp. were detected. By the way, in the semi purified toxins from the viscera of Camotes sample, relative abundances (mole \%) of neoSTX, dcSTX and STX were rather high $(89 \%)$, and $11 \%$ of GTX4 were contained in addition to smaller amounts (3\%) of hyneoSTX (Figure 5). PSP compositions were almost the same as that of Ishigaki specimens, but in HPLC-FLD analysis of TTX, trace amount of TTX was detected (data not shown). 
Furthermore, ion-monitored mass chromatograms of TMS derivatives of alkali-hydrolyzed toxin and authentic TTX in the GC-MS method are shown in Figure 6. Mass fragment ion peaks at $m / z$ 376, 392 and 407, which are characteristic of the quinazoline skeleton, appeared at almost the same retention times of 15.12 and $15.16 \mathrm{~min}$, respectively, and along with TMS-C9 base derived from authentic TTX with a retention time of $15.14 \mathrm{~min}$. The crab toxin and standard TTX had the same mass spectra with mass fragment ions peaks at $\mathrm{m} / z 407$ (molecular peak), 392 (base peak) and 376. Therefore, from the results of HPLC-FLD and GC-MS analysis, it can be concluded that the toxin in A.floridus from Camotes Is. is a mixture of PSP and a trace amount of TTX.

As seen in our present study, in the toxic crabs living on reefs of Ishigaki Is., STX was predominant. However, A.floridus inhabiting Kojima, a small islet near site A and B (Fig.1), as seen in the Pacific coasts of Japan Proper, had TTX and/or its derivatives of as major toxins[28].

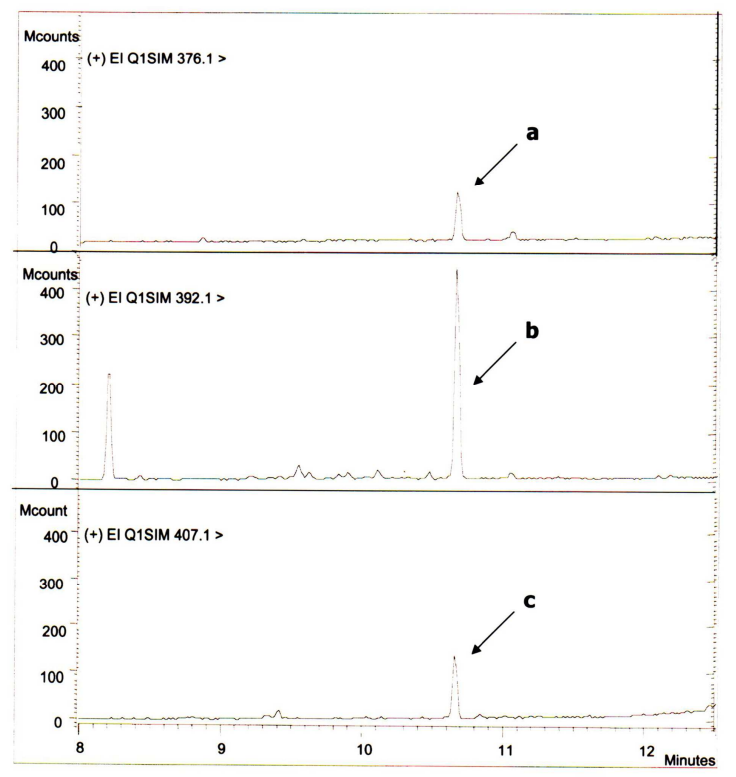

Figure 6. GC-MS analysis of TMS derivative of C9 base in paralytic toxins from A. floridus collected from Camotes Island, Cebu Province, Philippines $a, m / z=376 ; b, m / z=392 ;$ and $c, m / z=407$

In this connection, it was previously reported that TTX is the major toxin, and GTX 1 and, 3 are minor toxins in $L$. pictor (xanthid crab from Taiwan) [29]. In contrast, in crabs from Negros Island, Philippines, PTX was found to be the predominant toxin [30,31].

On the other hand, TTX and PSP are the major and minor toxins, respectively, in A.floridus inhabiting Miura Peninsula, Kanagawa Prefecture, Japan [9], which differs from the same species used in this study. A.floridus specimen from Fiji Island was found to have, STX and STX derivatives as major toxins [24]. This indicated that the crab toxin might be of exogenous rather than endogenous origin. Through a complex system of trophic interrelationships, non filter-feeding organisms can also be exposed to PSP and/or
TTX and thus accumulate and play a role as vectors in marine food web. Transport and accumulation of toxins in food chains are a common phenomenon, particularly in marine biota. The origin of neurotoxins in toxic xanthid crabs may be from toxic lower strata invertebrates. In order to elucidate the diet of A.floridus from site A, B and the Camotes Is., microscopic examination of stomach contents of the species is needed. It was reported that PSP-containing A.floridus maintains a fairly high toxicity level for a long period when fed nontoxic diets (Noguchi et al., personal communication). This observation may suggest that PSP in this toxic crab mentioned above be endogenous. Oikawa [32] showed the presence of PSP toxins in the viscera of the edible shore crab Telmessus acutidens. It was also revealed that the total toxicity in the crab viscera increased linearly with the amount of toxic mussels the crabs ingested by feeding experiments [33].

Further studies are now in progress to elucidate the associated mechanism of toxicity. The accumulation mechanism or exact metabolic pathway of the toxins in xanthid crabs remains to be elucidated. As the screening of alga in the reef in Ishigaki island and Camotes Island are now on progress, the results will be published in elsewhere.

\section{Acknowledgements}

This work was partly supported by a JSPS-DOST Core University Program in Fisheries Sciences and by a Grant-in-Aid for Scientific Research from JSPS.

\section{References}

[1] M. Asakawa, K. Miyazawa, H. Takayama, and T. Noguchi, "Dinoflagellate Alexandrium tamarense as the source of paralytic shellfish poison (PSP) contained in bivalves from Hiroshima Bay, Hiroshima Prefecture, Japan”, Toxicon, vol.33, pp. 691-697, 1955.

[2] M. Asakawa, H.Takayama, R.Beppu, and K.Miyazawa, "Occurrence of paralytic shellfish poison (PSP) - producing dinoflagellate Alexandrium tamarense in Hiroshima Bay, Hiroshima Prefecture, Japan, during 1993-2004 and its PSP profiles", Journal of the Food Hygienic Society of Japan, vol.46, pp.246-250, 2005.

[3] R.Beppu, K.Nojima, S. Tsuruda, G.G.Delan, M.B.Quilantang, S.Taniyama, T. Sagara, S.Nishio, H.Takayama, K.Miyazawa and M.Asakawa, "Occurrence of PSP-Producing dinoflagellate Alexandrium tamiyavanichii in Bingo-Nada, the central coastal water of the Seto Inland Sea, Hiroshima Prefecture, Japan", Marine Pollution Bulletin, vol.56, pp.758-763, 2008.

[4] T. Noguchi, S.Konosu, and Y.Hashimoto, "Identity of the crab toxin with saxitoxin", Toxicon, vol.38, pp.763-773, 1969.

[5] T. Yasumoto, Y. Oshima, and T.Konta, "Analysis of paralytic shellfish toxins of xanthid crabs in Okinawa", Bulletin of the Japanese Society of Scientific Fisheries, vol.47, pp. 957-959, 1981. 
[6] K.Koyama, T.Noguchi, Y.Ueda, and K.Hashimoto, "Occurrence of neosaxitoxin and other paralytic shellfish poisons in toxic crabs belonging to the family Xanthidae", Bulletin of the Japanese Society of Scientific Fisheries, vol.47, pp.965, 1981.

[7] K.Shiomi, H. Inaoka, H. Yamanaka, and T. Kikuchi, "Occurrence of a large amount of gonyautoxins in a xanthid crab Atergatis floridus from Chiba", Bulletin of the Japanese Society of Scientific Fisheries, vol.48, pp.1407-1410, 1982.

[8] T.Noguchi, K.Koyama, A.Uzu, and K.Hashimoto, "Local variation of toxicity and toxin composition in a xanthid crab Atergatis floridus", Bulletin of the Japanese Society of Scientific Fisheries, vol.49, pp.1883-1886, 1983.

[9] T.Noguchi, A.Uzu, K.Koyama, J.Maruyama, Y.Nagashima and K.Hashimoto, "Occurrence of tetrodotoxin as the major toxin in a xanthid crab Atergatis floridus", Bulletin of the Japanese Society of Scientific Fisheries, vol.49, 1887-1892., 1983.

[10] P.K.L, Ng, D.Guinot and P.J.F.Davie, "Systema brachyurorum; Part I. An annotated checklist of extant brachyuran crabs of the world", The Raffles Bulletin of Zoology, vol.17, pp.1-286, 2008.

[11] T. Kawabata, "Assay method for paralytic shellfish poison" In: Food Hygiene Examination Manual, (Environmental Health Bureau, Ministry of Health and welfare, ed.), Japan Food Hygiene Association, Tokyo, vol. 2, pp. 240-244, 1978.

[12] M.Asakawa, G. G.Delan, S. Tsuruda, M. Shimomura, Y. Shida, S. Taniyama, M. B.Quilantang and J. Shindo., "Toxicity assessment of the xanthid crab Demania cultripes from Cebu Island, Philippines", Journal of Toxicology, Article ID 172367, 7pages, 2010.

[13] M.Asakawa, T.Toyoshima, Y.Shida, T. Noguchi and K.Miyazawa, "Paralytic toxicity in the ribbon worm Cephalothrix species (Nemertean) adherent to cultured oysters in Hiroshima Bay, Hiroshima Prefecture, Japan", Toxicon, vol.38, pp.763-773, 2000.

[14] M.Asakawa, T.Toyoshima, K.Ito, K.Bessho, C.Yamaguchi, S.Tsunetsugu, Y.Shida, H.Kajihara, S.F.Mawatari, T.Noguchi and K.Miyazawa, "Paralytic toxicity in the ribbon worm Cephalothrix species (Nemertea) in Hiroshima Bay, Hiroshima Prefecture, Japan and the isolation of tetrodotoxin as a main component of its toxins", Toxicon, vol41, pp.747-753, 2003.

[15] T.Noguchi, M. Kohno, Y.Ueda and K.Hashimoto., "Isolation of gonyautoxin-2, a main component of paralytic shellfish poison from toxic scallop and its properties", Journal of the Chemical Society of Japan, vol.5, pp.652-658, 1981.

[16] K.Daigo, K., Uzu, A., O.Arakawa, T.Noguchi, H.Seto and K.Hashimoto, "Isolation and some properties of neosaxitoxin from a xanthid crab Zosimus aeneus ", Bulletin of the Japanese Society of Scientific Fisheries, vol.51, pp.309-313. 1985.

[17] H.Narita, T.Noguchi, J.Maruyama, Y.Ueda, K.Hashimoto, Y.Watanabe and K.Hida, "Occurrence of tetrodotoxin in a trumpet shell, "Boshubora" Charonia sauliae", Bulletin of the Japanese Society of Scientific Fisheries, vol.47, pp.935-941.1981
[18] O.Arakawa, Y.Noguchi and Y.Onoue, "Paralytic shellfish toxin profiles of xanthid crabs Zosimus aeneus and Atergatis floridus collected on Reefs of Ishigaki Island", Fisheries Science, vol.61, 659-662, 1995

[19] E.E.Carumbana, A.C.Alcala and E.P.Ortega, "Toxic marine crabs in southern Negros, Philippines", Silliman Journal, vol.23, pp.265-278, 1976.

[20] A.C.Alcala and B.W.Halstead, "Human Fatality Due to Ingestion of the Crab Demania sp. in the Philippines", Clinical Toxicology, vol.3, pp.609-611, 1970.

[21] A.C.Alcala, "Recent cases of crab, cone shell, and fish intoxication of southern Negros Island, Philippines", Toxicon, vol.21, supplement 3, pp.1-3, 1983.

[22] R.B.Gonzales and A.C.Alcala, "Fatalities from crab poisoning on Negros Island, Philippines", Toxicon, vol.15, pp.169-170, 1977.

[23] K.Hashimoto and T.Noguchi, "Recent studies on paralytic shellfish poison in Japan", Pure \& Appl. Chem., vol.61, pp.7-18, 1989.

[24] U.Raj, H.Haq, Y.Oshima and T.Yasumoto. "The occurrence of paralytic shellfish toxins in two species of xanthid crab from Suva Barrier Reef, Fiji Islands", Toxicon, vol.21, pp.547-551, 1983.

[25] Y.Kotaki, M.Tajiri, Y.Oshima and T.Yasumoto, "Identification of a calcareous red alga as the primary source of paralytic shellfish toxins in coral reef crabs and gastropods", Bulletin of the Japanese Society of Scientific Fisheries, vol.49, pp.283-286, 1983.

[26] T.Yasumoto, H.Nagai, D.Yasumura, T.Michishita, T.Endo, M.Yotsu and Y.Kotaki, "Interspecies Distribution and Possible Origin of Tetrodotoxin", Annals of the New York Academy of Science, vol.479, pp.44-51, 1986.

[27] T.Saisho, T.Noguchi, K.Koyama, A.Uzu, T.Kikuta and K.Hashimoto, "Examination of stomach contents in xanthid crabs", Bulletin of the Japanese Society of Scientific Fisheries, vol.49, pp.939-947, 1983.

[28] O.Arakawa, T.Noguchi, Y.Shida and Y.Onoue, "Occurrence of 11-oxotetrodotoxin and 11-nortetrodotoxin-6(R)-ol in a xanthid crab Atergatis floridus collected at Kojima, Ishigaki Island", Fisheries. Scencei, vol.60, pp.769-771, 1994.

[29] Y.H.Tsai, D.F.Hwang, T.J.Chai and S.S.Jeng, "Occurrence of tetrodotoxinand paralytic shellfish poison in the Taiwanese crab Lophozozymus pictor", Toxicon, vol.33, pp.1669-1673, 1995.

[30] T.Yasumoto, D.Yasumura, Y.Ohizumi, M.Takahashi, A.C.Alcala and L.C.Alcala, "Palytoxins in two species of xanthid crabs from the Philippines", Agricultural and Biological Chemistry, vol.50, pp.163-167, 1986.

[31] A.C.Alcala,,L.C.Alcala, J.S.Garth, D.Yasumura and T.Yasumoto., "Human fatality due to ingestion of the crab Demania reynaudii that contained a palytoxin-like toxin", Toxicon, vol.26, pp.105-107.

[32] H.Oikawa, T.Fujita, M.Satomi, T.Suzuki, Y.Kotani and Y.Yano, "Accumulation of paralytic shellfish poisoning toxins in the edible shore crab Telmessus acutidens" Toxicon, vol.40, pp.1593-1599, 2002. 
[33] H.Oikawa, M.Satomi, S.Watabe and Y.Yano, "Accumulation and depuration rates of paralytic shellfish poisoning toxins in the shore crab Telmessus acutidens by feeding toxic mussels under laboratory controlled conditions", Toxicon vol.45, pp. 163-169, 2005. 